\title{
Deskripsi Karakter Tanggung Jawab Berdasarkan Indikator Tanggung Jawab Terhadap Tata Tertib Dan Tanggung Jawab Terhadap Peraturan di SMP Adhyaksa 1 Kota Jambi
}

\author{
Amirullah ${ }^{1}$, Roro Hoyi ${ }^{2}$ \\ ${ }^{1}$ SMAN 1 Muaro Jambi, Jambi, Indonesia \\ ${ }^{2}$ Pendidikan Fisika, Universitas Jambi Indonesia
}

\begin{tabular}{l} 
Article Info \\
\hline Article history: \\
Received Jun 26, 2020 \\
Revised Jul 28, 2020 \\
Accepted Sep 3, 2020 \\
\hline
\end{tabular}

Keywords:

Karakter

Tanggung Jawab

Siswa SMP

\begin{abstract}
ABSTRAK
Tujuan Penelitian: Mendeskripsikan tanggung jawab siswa di SMP Adhyaksa 1 kota jambi berdasarkan indikator tanggung jawab terhadap tata tertib dan tanggung jawab terhadap peraturan.
\end{abstract}

Metodologi: Penelitian ini termasuk kedalam penelitian explanatory desain. Data kuantitatif diperoleh menggunakan angket dan data kualitatif diperoleh menggunakan lembar wawancara. Subjek dari penelitian ini berjumlah 116 siswa yang berasal dari SMP Adhyaksa 1 Kota Jambi.

Temuan utama: Dari penelitian yang telah dilakukan didaptkan hasil bahwa peserta didik di SMP Adhyaksa 1 Kota Jambi memiliki karakter tanggung jawab yang baik dalam bertanggung jawab terhadap tata tertib dan peraturan.

Keterbaruan penelitian: Keterbaruan pada penelitian ini dlihat dari segi indicator yang digunakan selama peneitian.

This is an open access article under the $\underline{C C B Y-N C}$ license

Corresponding Author:

Roro Hoyi,

Pendidikan Fisika, Universitas Jambi, Jambi, Indonesia

Email: rorohoyi31@gmail.com

\section{PENDAHULUAN}

Pendidikan adalah proses dalam meraih cita-cita yang diinginkan. Pendidikan adalah tujuan yang dilakukan seseorang untuk mendapatkan pengetahuan, keterampilan, dan kebiasaan dalam hidup [1]. Salah satu upaya dalam bidang pendidikan yang dapat dilakukan untuk mencetak SDM yang berkualitas yaitu dengan membiasakan membentuk budaya berpikir kritis pada siswa dalam proses pembelajarannya [2]. Menurut Asrial (2019) pendidikan adalah upaya untuk menciptakan sumber daya alam yang berkualitas dan sangat penting untuk meningkatkatkan pola pikir pendidikan di indonesia dalam proses belajar [3]. Proses pembelajaran membantu siswa/pelajar untuk mengembangkan potensi intelektual yang dimilikinya, sehingga tujuan utama pembelajaran adalah usaha yang dilakukan agak intelek setiap pelajar dapat berkembang [4]. Proses pembelajaran merupakan kegiatan yang dirancang untuk membantu seseorang mempelajari suatu kemampuan dan atau nilai yang baru dalam dunia pendidikan [5]. Pendidikan juga merupakan dasar untuk menumbuh kembangkan potensi sumber dari daya pikir peserta didik. Didalam proses pendidikan ini ada beberapa tingkatan pendidikan di Indonesia terdapat beberapa tingkatan, yaitu salah satunya tingkat Sekolah Menengah Atas (SMA). Sekolah Menengah Atas adalah tingkat pendidikan yang harus ditempuh oleh peserta didik, sebelum melanjutkan ke tahap pendidikkan ke tingkatan yang lebih tinggi [6]. Menurut Syahrial (2019) "Education is a very important activity, with the behavior and knowledge for the better" [7]. 
Salah satu jenjang pendidikan yang menarik perhatian umum adalah jenjang pendidikan SMP. Pendidikan di tingkat SMP dapat dikatakan kurang optimal, terutama untuk para peserta didik. Peserta didik di SMP masih kurang peduli dengan adanya pendidikan atau proses pembelajaran, justru mereka merasakan kebosanan saat proses pembelajaran berlangsung [8]. Pada jenjang SMP ini peserta didik lebih banyak mendalami pelajaran sains, pelajaran sains (IPA) ini adalah pelajaran wajib untuk pendidikan. Mata pelajaran IPA di tingkat SMP terutama yang memiliki kontribusi untuk menjadikan peserta didik mampu menjadi generasi yang memiliki sikap ilmiah dalam kehidupan maupun lingkungannya [9]. Menurut Haryanto (2017) Ilmu Pengetahuan Alam (IPA) merupakan bagian dari ilmu sains [10].

IPA (Ilmu Pengetahuan Alam) adalah pengetahuan yang dalam implementasinya memerlukan pembuktian dan kebenaran tentang hukum alam yang dibuktikan dengan metode ilmiah [11]. Dalam proses pembelajaran yang dilakukan oleh seorang siswa, bagaimana sikap siswa tersebut terhadap mata pelajaran IPA itu sangat lah penting. Dalam pembelajaran IPA Siswa dituntut untuk selalu aktif, karena dalam proses pembelajaran, siswa tidak hanya diharuskan menguasai berbagai konsep tetapi juga diharuskan untuk membentuk kepribadian siswa yang baik [12]. Sikap merupakan salah satu faktor yang mempengaruhi proses pembelajaran yang berasal dari dalam diri siswa [13]. Sikap peserta didik terhadap pembelajaran IPA dapat dibentuk dimulai dari dasar, sehingga dampak dari sikap yang diperolah sangat berpengaruh pada latar belakang pendidikan peserta didik [14]. Siswa selalu menunjukkan sikap yang terbuka dan bersemangat dalam menghadapi mata pelajaran IPA baik itu didalam maupun dilluar kelas yang menunjukkan siswa tersebut senang terhadap mata pelajaran IPA [15]. Sebagai agen perubahan, pendidik diharapkan mampu menanamkan ciri-ciri, sifat dan watak serta jiwa mandiri, tanggung jawab dan cakap dalam kehidupan kepada peserta didik [16].

Sikap ilmiah pada pembelajaran IPA diantaranya yaitu berpikir logis, terbuka, rasa ingin tahu, disiplin, mandiri, jujur, kreatif, inovatif, rasa ingin tahu, tidak mudah putus asa, dan bertanggung jawab [17]. Menurut Syahrial (2019), tanggung jawab dalam belajar adalah kewajiban untuk menyelesaikan tugas yang telah diterima secara tuntas melalui usaha yang maksimal serta berani menanggung segala akibatnya [18]. Oleh sebab itu, karakter tanggung jawab ini sangat penting diterapkan dalam pendidikan IPA. karakter tanggung jawab ini sangat penting didalam pendidikan terutama untuk peserta didik.

Menurut Ardilla (2017), karakter tanggung jawab siswa di sekolah masih rendah dapat dilihat dari rendahnya hasil belajar siswa, kurangnya keaktifan siswa, siswa sering tidak melaksankan tugas-tugasnya, siswa tidak menepati janjinya, bahkan tawuran atau tidakan bullying di sekolah [19]. Serta banyak peserta didik merasa terbebani dengan kewajibannya menjadi seorang pelajar [20].

Penelitian ini bertujuan untuk mengetahui bagaimana sikap siswa terhadap pembelajaran IPA di SMP Adhyaksa 1 Kota Jambi. Terdapat 2 indikator yaitu: Tanggung jawab terhadap tata tertib dan Tanggung jawab terhadap peraturan kelas. Dalam penelitian ini pertanyaan penelitian sebagai berikut :

1. Apakah peserta didik bertanggung jawab terhadap peraturan dikelas?

2. Apakah peserta didik bertanggung jawab terhadap tata tertib disekolah?

Temuan penelitian ini dapat berkontribusi untuk meningkatkan sikap peserta didik terhadap tanggung jawab.

\section{METODE PENELITIAN}

Desain penelitian yang digunakan adalah metode penelitian mixed methods (penelitian kombinasi). Menurut Axinn (2006), Mixed method data collection strategies are those that are explicitly designed to combine elements of one method [21]. Pada penelitian ini, peneliti menggabungkan antara penelitian kualitatif dan kuantitatif. "Quantitative research is an approach for testing objective theories by examining the relationship among variables" [22]. Dari pendapat diatas sesuai dengan objek yang kami teliti yaitu ranah sikap dari siswa dan cara kami mengumpulkan informasi sebanyak-banyaknya dari siswa dengan menyebarkan angket Rancangan penelitian ini diterapkan karena sesuai dengan tujuan penelitian yakni untuk mengetahui Sikap Siswa SMP terhadap mata pelajaran IPA. Populasi pada penelitian ini yaitu 116 siswa dari SMP 16 Kota Jambi, yang terbagi kedalam 5 kelas.

Dalam penelitian ini menggunakan dua buah instrumen penelitian yaitu menggunakan angket dan menggunakan wawancara. Pengumpulan data penelitian dilaksanakan dengan menggunakan teknik tes dan wawancara [23]. Dengan 56 butir pernyataan valid dan Cronbach Alpha sebesar 0,842 dimana angket tersebut dikatakan reliable atau layak untuk digunakan. angket ini menggunakan skala Likert. Menurut Sugiyono (2018), dengan menggunakan skala Likert maka variabel - variabel yang digunakan dijabarkan menjadi indikator variable [24]. dalam penelitian yang dilakukan Astalini dan Kurniawan tersebut menggunakan skala Likert dengan model lima pilihan (skala lima), Maksudnya adalah responden melakukan pengisian angket sikap terhadap mata pelajaran IPA dengan memberikan tanda ceklis $(\sqrt{ })$ pada pilihan jawaban yang telah disediakan, yaitu: 1) Sangat Tidak Setuju (STS) ; 2) Tidak Setuju (TS); 3) Netral (N); 4) 
Setuju (S); 5) Sangat Setuju (SS). dan pertanyaan wawancara diambil dari indikator penelitian yang digunakan dalam menyusun pernyataan pada angket penelitian.

\section{HASIL DAN PEMBAHASAN}

Hasil dari penelitian ini ditujukan untuk mengetahui bagaimana karakter tanggung jawab siswa di SMP Adhyaksa 1 Kota Jambi dapat dilihat pada tabel 1 dan 2.

Tabel 1 Tanggung Jawab terhadap tata tertib

\begin{tabular}{ccccccc}
\hline Variabel & Interval & Frekuensi & $(\%)$ & Kategori & & \\
\hline Tanggung & $4,0-8,0$ & 1 & 0,8 & Tidak Baik & Mean & 17,7 \\
jawab & $8,1-12,0$ & 6 & 4,6 & Cukup & Median & 17,0 \\
terhadap tata & $12,1-16,0$ & 19 & 25,4 & Baik & Modus & 18,0 \\
tertib & $16,1-20,0$ & 90 & 69,2 & Sangat Baik & Min & 8,0 \\
& & & & & Max & 19,0 \\
\hline
\end{tabular}

Berdasarkan data pada tabel 1 dapat dipahami bahwa dari total 116 orang subjek yang merupakan siswa SMP Adhyaksa 1 Kota Jambi didapatkan sebanyak 1 orang atau ada 0,8\% siswa yang belum ada rasa tanggung jawab terhadap tata tertib, 6 siswa (4,6\%) dengan kategori cukup terhadap tanggung jawa terhadap tata tertib, 19 siswa $(25,4 \%)$ dengan kategori baik dalam tanggung jawab terhadap tata tertib dan 90 siswa $(69,2 \%)$ dengan kategori sangat baik dalam tanggung jawab terhadap tata tertib. Dengan mean 17,7 , median 17,00 modus 18,0 , minimum 8,00 dan maximum 19,00 .

Dapat disimpulkan bahwa pada indikator tanggung jawah terhadap tata tertib pada SMP Adhyaksa ini sudah memenuhi kategori sangat baik dalam bertanggung jawab terhadap tata tertib.

Tabel 2 Tanggung Jawab terhadap peraturan

\begin{tabular}{ccccccc}
\hline Variabel & Interval & Frekuensi & $(\%)$ & Kategori & & \\
\hline Tanggung & $4,0-11,0$ & 0 & 0 & Tidak Baik & Mean & 25,2 \\
jawab & $11,1-19,0$ & 7 & 5,1 & Cukup & Median & 25,0 \\
terhadap tata & $19,1-25,0$ & 66 & 48,5 & Baik & Modus & 28,0 \\
tertib & $25,1-32,0$ & 63 & 46,3 & Sangat Baik & Min & 13,0 \\
& & & & & Max & 32,0 \\
\hline
\end{tabular}

SMP Adhyaksa 1 Kota Jambi dipahami bahwa dari total 116 orang subjek sebanyak 0 orang atau ada $0 \%$ siswa yang belum ada rasa tanggung jawab terhadap tata tertib, 7 siswa $(5,1 \%)$ dengan kategori cukup terhadap tanggung jawa terhadap tata tertib, 66 siswa (48,5\%) dengan kategori baik dalam tanggung jawab terhadap tata tertib dan 63 siswa (46,3\%) dengan kategori sangat baik dalam tanggung jawab terhadap tata tertib. Dengan mean 25,2, median 25,00 modus 28,00, minimum 13,00 dan maximum 32,00. Dapat disimpulkan bahwa pada indikator tanggung jawah terhadap tata tertib pada SMP Adhyaksa ini sudah memenuhi kategori baik dalam bertanggung jawab terhadap tata tertib. Dari 2 indikator diatas dapat dilihat bahwa siswa sudah mencapai kategori baik dan sangat baik dalam tanggung jawab terhadap tata tertib dan peraturan disekolahnya. Itu karena sikap positif yang dimiliki masing-masing siswa sudah meningkat. waktu.

Pada penelitian ini dapat dilihat dari hasil data diatas bahwa SMP Adhyaksa ini peserta didik sudah baik dalam tanggung jawab terhadap tata tertib dan terhadap peraturan disekolahnya. Dengan mematuhi peraturan siswa akan tergolong dalam kategori baik. Sikap tanggung jawab siswa ini sangat penting dalam pendidikan, jika siswa tidak mempunyai rasa tanggung jawab maka siswa tersebut tidak akan belajar dengan baik. tanggung jawab dalam belajar adalah kewajiban untuk menyelesaikan tugas yang telah diterima secara tuntas melalui usaha yang maksimal serta berani menanggung segala akibatnya. Oleh sebab itu, karakter tanggung jawab ini sangat penting diterapkan dalam pendidikan IPA. pada saat observasi dapat dilihat bahwa siswa sangat rapi dalam berpakaian siswa juga mengerjakan tugas dengan baik serta datang kesekolah tepat waktu. Guru juga sangat memperhatikan siswa terhadap tanggung jawabnya. The teacher is an important instrument in realizing good learning [25]. Selain melakukan penilaian kognitif dan psikomotor, guru diharuskan untuk melakukan penilaian afektif (sikap), walaupun memerlukan waktu yang relatif lama [26].

Selain menggunakan angket alat yang digunakan untuk mengetahui sikap siswa terhadap mata pelajaran IPA, juga digunakan wawancara untuk mendukung hasil yang telah dilakukan. Adapun hasil wawancara yang digunakan yaitu :

Q:apakah mata pelajaran IPA itu termasuk kedalam mata pelajaran yang sulit?

A: iya, karena sulit dalam menghitung - hitung.

Q: menurut anda bagaimana cara memahami pelajaran IPA yang sulit?

A: Menanya Ke Guru Dan Menanya Ke Kawan 
$Q$ : Apa yang anda lakukan ketika anda bosan dengan mata pelajaran IPA?

A : Menyanyi nyanyi dan ganggu teman

Q: apakah kamu suka melakukan eksperimen atau percobaan?

A: suka.

$Q$ :apakah dengan mengetahui penerapan IPA dalam kehidupan sehari - hari meempermudahkan dalam memahami IPA?

A: Iya sangat membantu

Q: Apakah anda tertarik untuk bekerja dibidang IPA?

A: tidak karena menginginkan pekerjaan lain seperti Polwan

Q: apakah anda ingin menambah waktu belajar IPA?

A: Tidak karena membosankan.

Kesimpulan dari hasil wawancara diatas yaitu siswa pelajaran IPA membuat siswa sulit untuk memahami karena ada hitung-hitungannya. Sebagian peserta didik memiliki minat yang rendah terhadap pembelajaran IPA, siswa yang bersikap positif dalam pembelajaran akan antusias dan semangat dalam belajar [25]. Jika siswa semangat dalam belajar maka hasil belajar peserta didik akan meningkat, Dan tentunya dengan antusias itu siswa akan bertanggung jawab terhadap tugas-tugasnya.

\section{KESIMPULAN}

Dari hasil penelitian yang telah dilakukan dapat disimpulkan bahwa karakter tanggung jawab siswa di SMP Adhyaksa 1 Kota Jambi sudah termasuk dalam kategori baik, dimana dari jumlah Siswa pada tabel 1.2 tanggung jawab terhadap tata tertib dari total 116 orang subjek yang merupakan siswa SMP Adhyaksa 1 Kota Jambi didapatkan sebanyak 1 orang atau ada $0,8 \%$ siswa yang belum ada rasa tanggung jawab terhadap tata tertib, 6 siswa $(4,6 \%)$ dengan kategori cukup terhadap tanggung jawa terhadap tata tertib, 19 siswa $(25,4 \%)$ dengan kategori baik dalam tanggung jawab terhadap tata tertib dan 90 siswa $(69,2 \%)$ dengan kategori sangat baik dalam tanggung jawab terhadap tata tertib. Dan pada tabel 1.3 tanggung jawab terhadap peraturan bahwa dari total 116 orang subjek sebanyak 0 orang atau ada $0 \%$ siswa yang belum ada rasa tanggung jawab terhadap tata tertib, 7 siswa $(5,1 \%)$ dengan kategori cukup terhadap tanggung jawa terhadap tata tertib, 66 siswa $(48,5 \%)$ dengan kategori baik dalam tanggung jawab terhadap tata tertib dan 63 siswa $(46,3 \%)$ dengan kategori sangat baik dalam tanggung jawab terhadap tata tertib. Dari hasil yang telah disebutkan diatas dapat disimpulkan bahwa peserta didik di SMP Adhyaksa 1 Kota Jambi memiliki karakter tanggung jawab yang baik dalam bertanggung jawab terhadap tata tertib dan peraturan.

\section{UCAPAN TERIMA KASIH}

Ucapan terimaksih peneliti kepada pihak sekolah SMP Adhyaksa 1 Kota Jambi yang telah berpartisipasi dalam penelitian ini dan kepada pihak-pihak yang telah memberikan dukungan pada penelitian ini.

\section{REFERENSI}

[1] Asrial, Syahrial, Kurniawan, D. A .\& Perdana, R. Supporting Technology 4.0: Ethoconstructivist Multimedia for Elementary Schools. iJOE - Vol. 15, No. 14, pp. 54, 2019

[2] Fujika, A, Anggereini, E \& Budiarti, R. S. Analisis Kemampuan Berpikir Kritis Siswa Sma N 5 Kota Jambi Melalui Pembelajaran Berbasis Masalah Pada Konsep Pencemaran Lingkungan. Jurnal BIODIK, vol. 1, no. 1, 2015.

[3] Asrial, Syahrial., Kurniawan, D. A., \& Septiasari, R. Hubungan Kompetensi Pedagogik Dengan Kompetensi IPA Mahasiswa Pendidikan Guru Sekolah Dasar. Pedagogia: jurnal pendidikan, vol. 8, no. 2, 2019 doi: 0.21070 /pedagogia.v8i2.1872

[4] Haryanto., Bakar. A \& Ilah. M, A, N. "Studi Perbandinganhasil Belajar Pada Materi Tata Nama Senyawa Kimia Antara Model Kooperatif Tipe Stad Dengan Jigsaw Kelas X Sma Negeri 3 Kuala Tungkal”. J. Indo. Soc. Integ. Chem, vol. 7, no, 2, 2015.

[5] Abdurrahman, Gardjito \& Budiarti, R. Pengembangan Lembar Kegiatan Siswa Berbasis Penemuan Terbimbing Pada Materi Struktur dan Fungsi Jaringan Tumbuhan Kelas Xi Sma. Jurnal BIODIK, vol.1, no. 1, pp. 10-17 2015.

[6] Astalini, Kurniawan D.A \& Putri. A. D. Identifikasi sikap implikasi sosial dari IPA, ketertarikan menambah waktu belajar IPA, dan ketertarikan berkarir dibidang IPA siswa SMP se-kabupaten Muaro Jambi. Jurnal Tarbiyah: Jurnal Ilmiah Kependidikan, vol. 7, no. 2, pp. 93-108. 2018 
[7] Syahrial, Asrial, Kurniawan, D.A, Chan, F., Hariandi, A., Pratama, R.A., Nugrogo, P \& Septiasari, R. "The impact of etnocontructivism in social affairs on pedagogic competencies". International Journal of Evaluation and Research in Education (IJERE.),vol. 8, no. 3, 2019 DOI: 10.11591/ijere.v8i3.20242

[8] Jusita, M. L. "Pengembangan Nilai-Nilai Karakter dalam Aktivitas Belajar Menggunakan Media Pembelajaran "Pecango". Jurnal Teori dan Praksis Pembelajaran IPS, vol. 1, no. 1, pp. 22-26. 2016

[9] Astalini., Kurniawan, D. A., Melsayanti, R \& Destianti, A. Sikap Terhadap Mata Pelajaran Ipa Di Smp SeKabupaten Muaro Jambi. Lentera pendidikan, vol. 21, no. 2, 2018.

[10] Haryanto, Harizon \& Rantih, N. K. "Pengembangan Instrumen Penilaian Keterampilan Proses Dan Sikap Ilmiah Pada Materi Termokimia Kelas XI MIA SMA Negeri 10 Kota Jambi”. J. Indo. Soc. Integ. Chem, vol 8, no. 1, 2017

[11] Asrial, Syahrial, Kurniawan.,D.A \& Maretika, L.D. Analisis kompetensi pedagogik dan kompetensi ipa terhadap calon guru sekolah dasar pgsd fkip universitas jambi. Jurnal DIDIKA: Wahana Ilmiah Pendidikan Dasar, vol 4, no. 2, 2019.

[12] Darmaji, Kurniawan, D.A, Parasdila, H \& Irdianti. Deskripsi Keterampilan Proses Sains Mahasiswa pada Materi Termodinamika. Berkala Ilmiah Pendidikan Fisika, vol. 6, no. 3, pp. 345-353, 2018.

[13] Maison, Astalini, Kurniawan, D. A \& Yuniyarsih, S. "Deskripsi Sikap Siswa Sma Negeri Pada Mata Pelajaran Fisika", EDUSAINS, vol.10, no. 1. 2018

[14] Astalini, A., Kurniawan, D. A., \& Putri, A, D. Identifikasi sikap implikasi sosial dari IPA, ketertarikan menambah waktu belajar IPA, dan ketertarikan berkarir dibidang IPA siswa SMP se-kabupaten muaro jambi. Jurnal Tarbiyah Jurnal Ilmiah Kependidikan, vol. 7, no. 2, 93-108. 2019

[15] Astalini, A., Kurniawan, D. A., Sari, D. K., \& Kurniawan, W. Description of scientific normality, attitudes of investigation and interested career on physics in senior high school. JIPF (Jurnal Ilmu Pendidikan Fisika), vol. 4, no. 2, pp. 56-63. 2019

[16] Dewi, R,.Budiarti, R.S \& Aina, M. Pengembangan Lembar Kegiatan Peserta Didik (Lkpd) Bermuatan Pendidikan Karakter Dengan Model Pembelajaran Guided Inquiry Pada Materi Bakteri Bagi Siswa Kelas X Sekolah Menengah Atas. Jurnal BIODIK, vol 3, no. 1, 2017.

[17] Syafitri. R. "Meningkatkan Tanggung Jawab Belajar Melalui Strategi Giving Questions And Getting Answers Pada Siswa”. Jurnal Penelitian Dan Pengembangan Pendidikan, vol. 1, no. 2, pp. 57-63. 2017

[18] Syahrial, Asrial, Kurniawan, D.A \& Subandiyo, M. "Pedagogic Competence And Indonesian Language Competence Pre-Service Teacher Of Elementary Program”. International journal of scientific \& technology researc,.vol. 8, no. 10, 2019

[19] Ardila. R. M, Nurhasanah, \& salami. M. Pendidikan Karakter Tanggung Jawab dan Pembelajarannya Di Sekolah. Jurnal FKIP UNS, vol. 5, no. 2, pp. 23-29, 2017

[20] Sayekti. I. C. "Peran Pembelajaran IPA di Sekolah Dalam Membangun Karakter Anak". Prosiding Seminar Nasional dan Call For Papers, 140-146, 2015

[21] Axinn, W. G,. \& Pearce, L. D. Mixed Method Data Collection Strategie. United States of America : Cambridge University Pres, 2006

[22] Creswell, J. W. Research Design Qualitative, Quantitave, And Mixed Methods Approaches. London: SAGE., 2014

[23] Asrial, Syahrial, Kurniawan.,D.A \& Amalina.,N. Analisis Hubungan Kompetensi Bahasa Indonesia Terhadap Kompetensi Pedagogik Mahasiswa Pendidikan Guru Sekolah Dasar. Premiere Educandum: Jurnal Pendidikan Dasar dan Pembelajaran, vol. 9, no. 1, pp.1-8. 2019. Doi: 10.25273/pe.v9i1.2832

[24] Sugiyono. Metode penelitian : kuantitatif, kualitatif, \& R\&D. Bandung: Alfabeta, 2018

[25] Rahayu. R. P. “Implementasi Pembelajaran Nilai Tanggung Jawab Pada Siswa Kelas III Sd 1 Pedes Sedayu Bantul Tahun Pelajaran 2014/2015”. Jurnal Pendidikan Guru Sekolah Dasar, vol. 2, no. 5, pp. 152-160, 2016

[26] Maison, M., Asrial, A., \& Syaiful, S. "Peningkatan Aktivitas Belajar Siswa Pada Materi Fisika Melalui Kegiatan Lesson Study Di Smp 17 Kota Jambi”. Jurnal Pengabdian pada Masyarakat, vol.30, no.4, pp 55-60. 2015 